\title{
EFEKTIFITAS MODEL PEMBELAJARAN QUANTUM LEARNING DI TINJAU DARI METAKOGNITIF FISIKA SISWA DI SMAN 48 JAKARTA
}

\author{
Imas Ratna Ermawati ${ }^{1}$, Feli Cianda Adrin Burhendi ${ }^{1}$, Nurhabibi Harahap ${ }^{2}$, \\ Sugianta $^{2}$ \\ Pendidikan Fisika, FKIP,Universitas Muhammadiyah Prof.DR.HAMKA ${ }^{1}$ \\ SMA Negeri 48 Jakarta $^{2}$ \\ Email: imas_re@uhamka.ac.id
}

Diterima: 9 Januari 2020 Disetujui: 15 Maret 2020

\begin{abstract}
Abstrak
Fokus penelitian ini ada pada seberapa efektifnya model quantum learning mempengaruhi keterampilan metakognitif fisika siswa di SMAN 48 Jakarta. Populasi penelitian ini berjumlah 30 orang siswa pada kelas eksperimen. Jenis penelitian ini adalah jenis penelitian eksperimen yang menggunakan desain penelitian quasi experiment dengan bentuk one-group pretest-posttest design. Setelah diberikan perlakuan dengan model quantum learning terlihat adanya pergeseran kemampuan metakognitif siswa dari cukup terampil menjadi terampil. Ini menunjukan adanya pengaruh yang signifikan dari model pembelajaran quantum terhadap kemampuan metakognitif siswa yang pada akhirnya membuat siswa memiliki hasil belajar yang sangat baik. Ini juga sesuai dengan perhitungan secara statistik dimana didapat nilai $\mathrm{t}_{\mathrm{hitung}}=$ 2,98 dan $\mathrm{t}_{\text {tabel }}=1,69$, diketahui bahwa jika $\mathrm{t}_{\text {hitung }}>\mathrm{t}_{\text {tabel }}$ maka hipotesis diterima dan diketahui model pembelajaran quantum mempengaruhi kemampuan metakognitif siswa.

Kata Kunci: : Quantum Learning, Metakognitif, Quasi Experiment.
\end{abstract}

\begin{abstract}
The focus of this research is on how effectively the quantum learning model affects the physics meta-cognitive skills of students at SMAN 48 Jakarta. The research population consisted of 30 students in the experimental class. This type of research is a type of experimental research that uses a quasiexperimental research design in the form of one-group pretest-posttest design. After being treated with a quantum learning model, it can be seen that there is a shift in students' meta-cognitive abilities from skilled enough to skilled. This shows that there is a significant influence of the quantum learning model of learning on students' meta-cognitive abilities which in turn makes students have excellent learning outcomes. This is also in accordance with statistical calculations where $t_{\text {count }}=2.98$ and $t_{\text {table }}=1.69$, it is known that if $t_{\text {count }}>t_{\text {table }}$, the hypothesis is accepted and the known quantum learning model influences students' meta-cognitive abilities.
\end{abstract} Keywords: Quantum Learning, Meta-Cognitive, Quasi Experiment.

PENDAHULUAN parameter atau acuan dalam

Belajar merupakan hal yang prosesnya. Sehingga harus menjadi kompleks, banyak hal yang menjadi perhatian bagi para pendidik dalam 
Ermawati., Burhendi., Harahap., Sugianta - Efektivitas Model ...

melihat karakteristik peserta didik seperti keterampilan umum, persepsi dan pengetahuan, serta faktor lingkungan mempunyai peran penting untuk setiap prosesnya. Dalam proses pembelajaran pendidik diharapkan mampu membaca karakter yang dominan dari peserta didik. Perbedaan gaya belajar merupakan salah satu dari banyaknya karakteristik yang dimiliki oleh peserta didik dikarenakan setiap peserta didik memiliki gaya belajar yang berbeda satu dengan lainnya (Cianda, Burhendi, \& Abdurrozak, 2020; Özyurt \& Özyurt, 2015; Surahman \& Surjono, 2017).

Interaksi merupakan salah satu cara untuk mengetahui karakteristik peserta didik. Dari kegiatan interaksi ini peserta didik dapat melihat gaya belajar peserta didik dan menentukan proses belajar dan menentukan model pembelajaran yang ada didalam kelas nantinya.

Seperti yang diungkapkan oleh suratmi dan purnami bahwa Interaksi pendidik dengan peserta didik membuat peserta didik menjadi berkembang agar menjadi sumber daya manusia berkualitas.
Berkualitasnya sumber daya menjadi modal bagi suatu negara pada era globalisasi untuk dapat bersaing dan memenuhi tantangannya. Dalam era globalisasi tantangan baik skala besar maupun kecil harus dapat dihadapi oleh manusia tersebut. Kemampuan memecahkan masalah menjadi sangat penting untuk dimiliki oleh semua jenjang usia dari mulai anak-anak hingga menjadi orang dewasa, baik dalam usia produktif maupun nonproduktif yang didalamnya termasuk usia sekolah dan bekerja (Suratmi \& Purnami, 2017).

Pemilihan model pembelajaran menjadi sangat menentukan dalam meningkatkan hasil belajar peserta didik. Terlibatnya model pembelajaran pada proses pembelajaran sangat mempengaruhi pengalaman belajar dari peserta didik. Konkritnya proses pembelajaran membuat efektifitas pengalaman belajar yang diterima peserta didik menjadi tinggi. Dalam mengikuti proses pembelajaran dibutuhkan model pembelajaran yang menarik sehingga peserta didik menjadi antusias dalam mengikuti prosesnya dan bukan tak mungkin pula peserta 
Ermawati., Burhendi., Harahap., Sugianta - Efektivitas Model ...

didik mampu memahami materi yang diberikan. Proses seperti itu menjadikan pembelajaran lebih bermakna (Durrotul, Haryanto, \& Anitah, 2017).

Quantum Learning terbukti efektif untuk proses pembelajaran baik disekolah maupun dunia bisnis. Model pembelajaran ini pertama kali diperkenalkan di California pada supercamp oleh salah satu sekolah bisnis. Model Pembelajaran ini menggabungkan keterampilan belajar, kemampuan berkomunikasi serta rasa percaya diri peserta didik dengan kondisi lingkungan belajar yang menyenangkan. Inti dari model pembelajaran ini adalah membawa dunia mereka ke dunia kita atau bisa juga dikatakan antarkan dunia kita dalam lingkup mereka. Model ini memberikan suasana belajar yang dinamis dengan penyajian yang prima, lingkungan yang mendukung, fasilitas luwes, keterampilan belajar serta suasana yang kukuh (Rahayu, Joyoatmojo, \& Wahyuni, 2016).

$\begin{array}{ccc}\text { Quantum } & \text { Learning } & \text { dapat } \\ \text { diajadikan } & \text { alternatif } & \text { dalam }\end{array}$
pembaharuan proses belajar dengan menyajikan petunjuk praktis juga spesifik guna menciptakan kondisi belajar efektif. Model pembelajaran ini merupakan strategi, kiat, petunjuk, untuk seluruh proses pembelajaran yang dapat meningkatkan pemahaman serta daya ingat dan membuat aktifitas belajar menjadi menyenangkan dan bermanfaat (Herfinayanti, Amin, \& Azis, 2017).

Pelaksanaan model pembelajaran Quantum Learning memperhatikan faktor internal yang ada dalam diri peserta didik dan juga memperhatikan faktor eksternal peserta didik seperti lingkungan belajar. Model pembelajaran ini juga mengonsep (melakukan penataan pentas untuk lingkungan belajar yang tepat). Penataan lingkungan ini ditujukan sebagai upaya dalam mempertahankan sikap positif (Arifin \& Lesmono, 2016).

Demi meningkatkan hasil belajar fisika siswa yang signifikan dalam proses pembelajaran dengan menggunakan model quantum learning kami menggunakan pendekatan keterampilan metakognitif. Kami memilih pendekatan keterampilan metakognisi dikarenakan metakognisi sangat 
Ermawati., Burhendi., Harahap., Sugianta - Efektivitas Model ...

mempengaruhi pemahaman peserta didik. Keterampilan metakognisi mempengaruhi banyak hal seperti pemahaman, penyimpanan serta penerapan dari apa yang sudah dipelajari oleh peserta didik, selain itu jugamempengaruhi berpikir kritis, ketangkasan dalam belajar hingga pemecahan masalah. Keterampilan metakognitif memungkinan melakukan pengaturan diri dalam proses belajar dan produk (Khoiriah, 2015).

Fokus dari metakognitif adalah memecahkan suatu masalah dalam sebuah proses belajar berpikir tingkat tinggi dengan kontrol aktif untuk proses pembelajarannya ditinjau dari aspek kognitif. Pendekatan tugas yang diberikan, pemahaman serta evaluasi tugas merupakan kognitif alami (Iskandar, 2014).

Dalam konteks pembelajaran, peserta didik mengetahui proses, kemampuan dan modalitas serta strategi belajar untuk menjadi belajar efektif. Dimana keberhasilan belajar seseorang dipengaruhi oleh keterampilan metakognitifnya karena setiap proses pembelajaarannya dilakukan dengan indikator dari pembelajaran how to learn sehingga hasil pembelajaran menjadi optimal.(Iin \& Sugiarto, 2012) Mengembangkan keterampilan metakognitif merupakan faktor penting dalam proses pembelajaran dikarenakan peserta didik menjadi mudah memahami setiap proses belajarnya sehingga pengetahuan menjadi mudah didapat (Putri, Priyono, \& Prasetyo, 2012).

Kecerdasan intelektual anak ditentukan oleh perkembangan kognitif. Perkembangan kognitif yang dimaksud adalah kemampuan untuk mengatur keterampilan kognitif dalam merespon suatu masalah (Aisyah \& Ridlo, 2015).

\section{METODE}

Desain penelitian ini menggunakan Quasi Experiment (Eksperimen semu) dikarenakan kita tidak mungkin mengontrol setiap variabel yang anggap relevan. Dengan bentuk one group pretest posttest design menggunakan satu kelompok kelas dengan fokus pengamatan pada kondisi sebelum dan sesudah dilakukan perlakuan, dan dilihat perubahan perilaku atau pencapaian 
Ermawati., Burhendi., Harahap., Sugianta - Efektivitas Model ...

dari individu setelah dilakukan penelitian ini dapat dilihat memalui perlakuan.(Fadilah, 2015) Gambaran tabel 1:

Tabel 1. One Group Pretest Posttest Design

\begin{tabular}{cccc}
\hline Group & Pretest & Perlakuan & Posttest \\
\hline 1 & $\mathrm{O} 1$ & $\mathrm{X}$ & $\mathrm{O} 2$ \\
\hline
\end{tabular}

Keterangan:

O1 : Pengukuran dilakukan sebelum dilakukan perlakuan dengan model quantum learning dengan keterampilan metakognitif

$\mathrm{X}$ : model quantum learning dengan keterampilan metakognitif

O2 : Pengukuran dilakukan sesudah dilakukan perlakuan dengan model quantum learning dengan keterampilan metakognitif

\section{HASIL DAN PEMBAHASAN}

Data penelitian yang kami peroleh selama penelitian di SMAN 48 Jakarta berupa nilai hasil pretest pada awal pertemuan dan posttest pada akhir pertemuan.

Hasil observasi menunjukkan antusiasme siswa dalam mengikuti setiap gerakan sehingga dapat melatih kinestetik siswa. Ketika guru menyampaikan pentingnya materi pelajaran maka siswa sangat antusias dalam mengikuti pelajaran serta siswa mengetahui manfaat mempelajari gerak benda. Makin tepat motivasi yang diberikan, akan makin berhasil pula hasil belajar. Jadi motivasi akan senantiasa menentukan intensitas usaha belajar bagi siswa. Peningkatan proses pembelajaran jika ditinjau dari aktivitas mengajar guru dan aktivitas siswa mengalami peningkatan pada setiap pertemuannya. Peningkatan ini berpengaruh terhadap peningkatan hasil belajar siswa. Pencapaian hasil belajar siswa dapat dilihat pada kategorisasi hasil belajar siswa,

Kategori pretest pada umumnya siswa berada pada kategori tidak terampil, cukup terampil dan terampil. Sedangkan pada nilai posttest pada umumnya siswa berada pada kategori terampil. Hal ini menujukkan bahwa adanya peningkatan hasil belajar siswa yang awalnya berada pada kategori tidak 
Ermawati., Burhendi., Harahap., Sugianta - Efektivitas Model ...

terampil, setelah diterapkan model pembelajaran quantum dengan kemampuan metakognitif, hasil belajar siswa berada pada kategori terampil (Supramono, 2016).
Nilai Pretest seperti ditunjukkan pada tabel 2 diperoleh diawal pertemuan tanpa memberikan perlakuan apapun untuk mengetahui kondisi awal siswa.

Tabel 2. Nilai Hasil Pretest sebelum diberikan perlakuan menurut keterampilan metakognitif

\begin{tabular}{cccc}
\hline \multirow{2}{*}{ Nilai } & \multicolumn{2}{c}{ Pretest } & \multirow{2}{*}{ Kategori } \\
\cline { 2 - 3 } & Siswa & Persen & \\
\hline $0-20$ & 0 & 0,0 & STT \\
$21-40$ & 1 & 3,3 & TT \\
$41-60$ & 19 & 63,3 & CT \\
$61-80$ & 10 & 33,3 & T \\
$81-100$ & 0 & 0,0 & ST \\
\hline Jumlah & 30 & 100 & \\
\hline
\end{tabular}

Setelah diketahui kondisi awal kami memberikan perlakuan terhadap siswa dengan menerapkan model pembelajaran quantum learning dengan memberikan model soal yang memicu keterampilan metakognitif siswa. Setelah diberikan perlakuan kami mengambil nilai posttest untuk melihat sejauh mana model ini mempengaruhi kemampuan metakognitif siswa. Data posttest kami sajikan dalam bentuk tabel 3 .

Tabel 3. Nilai Hasil Posttest sesudah diberikan perlakuan menurut keterampilan metakognitif

\begin{tabular}{cccc}
\hline \multirow{2}{*}{ Nilai } & \multicolumn{2}{c}{ Posttest } & \multirow{2}{*}{ Kategori } \\
\cline { 2 - 3 } & Siswa & Persen & \\
\hline $0-20$ & 0 & 0,00 & STT \\
$21-40$ & 0 & 0,00 & TT \\
$41-60$ & 1 & 3,30 & CT \\
$61-80$ & 27 & 90,00 & T \\
$81-100$ & 2 & 6,67 & ST \\
\hline Jumlah & 30 & 100 & \\
\hline
\end{tabular}


Nilai STT pada tabel 3 merupakan akronim dari sangat tidak terampil, TT merupakan singkatan dari tidak terampil, CT berarti cukup terampil, $\mathrm{T} \quad$ artinya terampil, dan ST yang dimaknai sangat terampil.
Jika diperhatikan dengan seksama grafik dan Histogram (N-GAIN) pada gambar 3, saat pretest dan posttest maka akan terlihat adanya pergeseran kemampuan metakognitif siswa dari cukup tidak terampil menjadi cukup terampil.

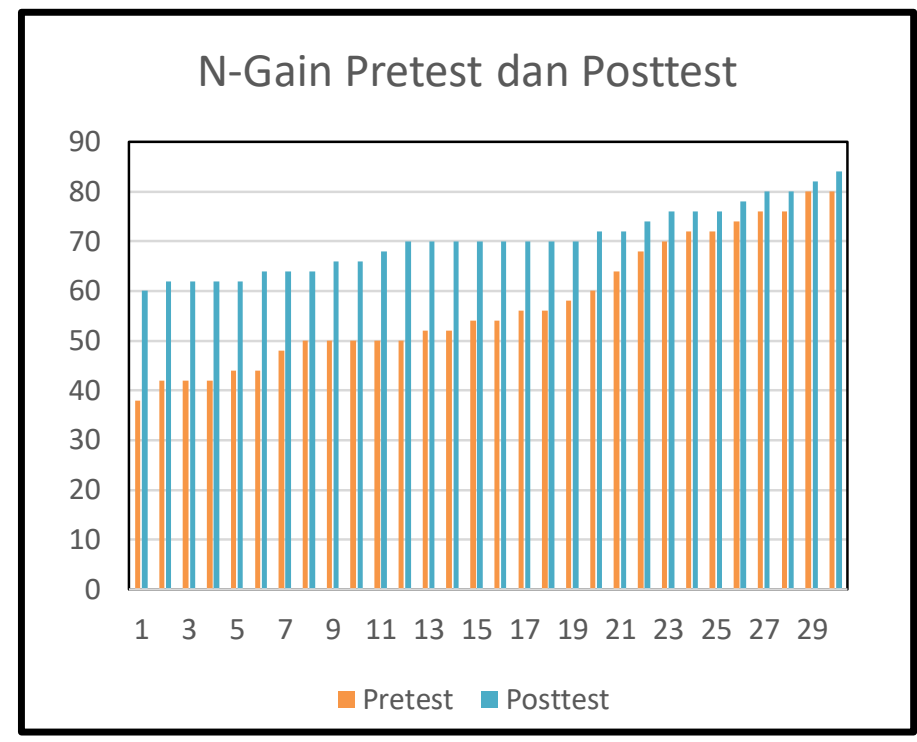

Gambar 3. Grafik Gain Individu peserta didik sebelum perlakuan (Pretest) dan sesudah perlakuan(Posttest).

Ini menunjukan adanya pengaruh 1,69, diketahui bahwa jika $t_{\text {hitung }}>$ yang signifikan dari model $t_{\text {tabel }}$ maka hipotesis diterima dan pembelajaran quantum learning diketahui model pembelajaran terhadap kemampuan metakognitif quantum learning mempengaruhi siswa yang pada akhirnya membuat kemampuan metakognitif siswa.

siswa memiliki hasil belajar yang sangat baik. Ini juga sesuai dengan Ucapan Terimakasih

perhitungan secara statistik dimana Terimakasih kepada Universitas didapat nilai $\mathrm{t}_{\text {hitung }}=2,98$ dan $\mathrm{t}_{\text {tabel }}=$ Muhammadiyah Prof. DR. HAMKA 
Ermawati., Burhendi., Harahap., Sugianta - Efektivitas Model ...

yang telah memberikan kami support

baik materi maupun moril sehingga

kami tim peneliti dosen pendidikan

fisika dapat menyelesaikan penelitian

ini. Terima kasih juga kami ucapkan

kepada Sekolah Menengah Atas

Negeri 48 Jakarta yang telah

mengizinkan kami untuk melakukan

penelitian dan kolaborasi bersama

guru bidang studi fisika sehingga

kami sebagai dosen juga

mendapatkan ilmu baru dalam

menghadapi kondisi real didalam

kelas tingkat sekolah menengah atas.

\section{KESIMPULAN DAN SARAN}

\section{Kesimpulan}

Sesuai dengan hasil dan pembahasan dari uji statistik dapat dikatakan bahwa ada tren positif dalam meningkatkan nilai dan keterampilan peserta didik jika kita menggunakan model quantum learning dengan fokus pendekatan keterampilan metakognitif. Dimana secara efektif model pembelajaran quantum learning dapat mempengaruhi proses belajar peserta didik sehingga peserta didik merasa nyaman dalam menikmati proses pembelajarannya, sehingga peserta didik dapat berekspresi dengan baik sehingga keterampilan kognitifnya pun meningkat dengan sendirinya.

\section{DAFTAR PUSTAKA}

Aisyah, S., \& Ridlo, S. (2015). Pengaruh Strategi Pembelajaran Jigsaw Dan Problem Based Learning Terhadap Skor Keterampilan Metakognitif Siswa Pada Mata Pelajaran Biologi. Unnes Journal of Biology Education, 4(1), 22-28.

Arifin, Z., \& Lesmono, A. D. (2016). Pengaruh Model Quantum Learning Disertai Metode Eksperimen Terhadap Hasil Belajar Fisika Siswa Di SMA Negeri Kalisat. Jurnal Pembelajaran Fisika, 4(4), 365370.

Cianda, F., Burhendi, A., \& Abdurrozak, A. (2020). The Implementation of Blended Learning Models Based Liveaboard Against Affective Aspects In Modern Physics Course. Gravity: Jurnal Ilmiah Penelitian Dan Pembelajaran Fisika, 6(1), 1-6.

Durrotul, F., Haryanto, S., \& Anitah, S. (2017). Model Pembelajaran Terpadu Modifikasi Wolfinger di Sekolah Dasar. Prosiding Seminar Pendidikan Nasional “ Pemanfaatan Smartphone Untuk Literasi Produktif Menjadi Guru Hebat Dengan Smartphone," 71-79.

Fadilah, R. (2015). Pengaruh Metoda Ruqyah terhadap Penurunan Derajat Kecemasan (Penelitian Quasi Experimental pada Pasien di Ruqyah X Cabang Bandung). 
Ermawati., Burhendi., Harahap., Sugianta - Efektivitas Model ...

Tazkiya: Journal of Psychology, 20(5).

Herfinayanti, Amin, B. D., \& Azis, A. (2017). Jurnal Pendidikan Fisika Universitas Muhammadiyah Makassar Penerapan Model Pembelajaran Quantum Learning Terhadap Hasil Belajar Fisika Siswa Kelas X SMA Negeri 1 Sungguminasa. Jurnal

Pendidikan Fisika Universitas Muhammadiyah Makasar, 5(1), 61-74.

Iin, Y., \& Sugiarto, B. (2012). Korelasi Antara Keterampilan Metakognitif Dengan Hasil Belajar Siswa Di Sman 1 Dawarblandong, Mojokerto. Unesa Journal of Chemical Education, 1(2), 78-83.

Iskandar, S. M. (2014). Pendekatan Keterampilan Metakognitif Dalam Pembelajaran Sains Di Kelas. ERUDIO, 2(2), 13-20.

Khoiriah, T. (2015). Strategi Pembelajaran Metakognitif Terhadap Hasil Belajar Siswa Pada Konsep Sistem Pencernaan Pada Manusia. Jurnal Pengajaran MIPA, 20(2), 177180.

Özyurt, Ö., \& Özyurt, H. (2015). Learning Style Based Individualized Adaptive ELearning Environments : Content Analysis of the Articles Published from 2005 to 2014. Elsevier: Computers in Human Behavior, 52, 349-358. https://doi.org/10.1016/j.chb.201 5.06.020

Putri, W. A., Priyono, A., \& Prasetyo,
B. (2012). Pengaruh Penerapan Strategi Metakognitif Dalam Metode Inkuiri Terhadap Hasil Belajar. Unnes Journal of Biology Education, 1(3), 266271.

Rahayu, T., Joyoatmojo, S., \& Wahyuni, S. (2016). Penerapan Model Pembelajaran Quantum Learning Dengan Metode Peta Pikiran (Mind Mapping) Sebagai Upaya Meningkatkan Hasil Belajar Siswa Dalam Mempelajari Ekonomi Kelas X MIA 1 SMA N 5 Surakarta Tahun Pelajaran 2015/2016. 121.

Supramono, A. (2016). Pengaruh Model Pembelajaran Quantum ( Quantum Teaching ) Terhadap Hasil Belajar IPA Siswa Kelas III SD YPS Lawewu Kecamatan Nuha Kabupaten Luwu Timur. Jurnal Nalar Pendidikan, 4(2), 78-86.

Surahman, E., \& Surjono, H. D. (2017). Pengembangan Adaptive Mobile Learning pada Mata Pelajaran Biologi SMA Sebagai Upaya Mendukung Proses Blended Learning. Jurnal Inovasi Teknologi Pendidikan, 4(1), 26-37.

Suratmi, \& Purnami, A. S. (2017). Pengaruh Strategi Metakognitif Terhadap Kemampuan Pemecahan Masalah Matematika Ditinjau Dari Persepsi Siswa Terhadap Pelajaran Matematika. UNION: Jurnal Pendidikan Matematika, 5(2), 183-194. 